Article

\title{
Sustainable Enzymatic Synthesis of a Solketal Ester-Process Optimization and Evaluation of Its Antimicrobial Activity
}

\author{
Patricia A. Mendoza-Ortiz ${ }^{1,2}$, Rafaela S. Gama ${ }^{3}$, Omar C. Gómez ${ }^{3}$, Jaine H. H. Luiz ${ }^{3}$, \\ Roberto Fernandez-Lafuente ${ }^{4, *(D)}$, Erika C. Cren ${ }^{1,2}$ and Adriano A. Mendes $1,3, *$ (D) \\ 1 Graduate Program in Chemical Engineering, Federal University of Minas Gerais, Belo Horizonte 31270-901, \\ MG, Brazil; paty_huu5@hotmail.com (P.A.M.-O); erika.cren@gmail.com (E.C.C.) \\ 2 Department of Chemical Engineering, Federal University of Minas Gerais, \\ Belo Horizonte 31270-901, MG, Brazil \\ 3 Institute of Chemistry, Federal University of Alfenas, Alfenas 37130-001, MG, Brazil; \\ rafaelasantosgama@gmail.com (R.S.G.); ramo75cab@gmail.com (O.C.G.); jainehh@gmail.com (J.H.H.L.) \\ 4 Departamento de Biocatálisis, ICP-CSIC, Campus UAM, Cantoblanco, 28049 Madrid, Spain \\ * Correspondence: rfl@icp.csic.es (R.F.-L.); adriano.mendes@unifal-mg.edu.br (A.A.M.); \\ Tel.: +34-91-595-4941 (R.F.-L.); +55-35-3701-9711 (A.A.M.)
}

Received: 22 January 2020; Accepted: 8 February 2020; Published: 11 February 2020

\begin{abstract}
The present study aims the enzymatic synthesis of solketal palmitate by esterification between solketal and palmitic acid using heptane as solvent. Lipases from Thermomyces lanuginosus (TLL), Candida rugosa type VII (CRL), and Pseudomonas fluorescens (PFL) were immobilized via interfacial activation on rice husk silica functionalized with triethoxy(octyl)silane $\left(\mathrm{Octyl}-\mathrm{SiO}_{2}\right)$ and used as biocatalysts. A loading of 20-22 mg of lipase/g of support was immobilized independently of the studied enzyme. TLL-Octyl- $\mathrm{SiO}_{2}$ was the most active biocatalyst in oil hydrolysis (656.0 $\pm 23.9 \mathrm{U} / \mathrm{g}$ ) and ester synthesis (productivity of $6.8 \mathrm{mmol} / \mathrm{min} . \mathrm{g}_{\text {biocat }}$ ), and it has been chosen for further ester synthesis optimization. The effect of some important parameters such as biocatalyst concentration, reaction temperature and acid:alcohol molar ratio on the reaction has been evaluated using a central composite rotatable design at fixed mechanical stirring ( $240 \mathrm{rpm})$ and reaction time (15 min). Subsequently, the effect of reactants concentration and molecular sieve concentration has also been examined. Under optimal conditions $\left(56^{\circ} \mathrm{C}\right.$, acid:alcohol molar ratio of $1: 3$ with a palmitic acid concentration of $1 \mathrm{M}$, and $20 \%$ wt. of TLL-Octyl- $\mathrm{SiO}_{2}$ per volume of reaction mixture), $83 \%$ acid conversion was obtained after $150 \mathrm{~min}$ of reaction. The biocatalyst retained $87 \%$ of its initial activity after seven successive reaction batches. The product was identified by nuclear magnetic resonance analysis. Antimicrobial activity studies showed that the synthesized ester demonstrated antifungal activity against Candida albicans and Candida parapsilosis, with minimum inhibitory concentration (MIC) between 200 and $400 \mu \mathrm{g} / \mathrm{mL}$, and bacteriostatic/fungistatic action-minimum microbicial concentration $(\mathrm{MMC})>400 \mu \mathrm{g} / \mathrm{mL}$.
\end{abstract}

Keywords: solketal ester; immobilized lipase; esterification; optimization; structural characterization; antimicrobial activity

\section{Introduction}

In the last years, the world production of biodiesel has generated a large volume of glycerol as a byproduct, which has become a promising feedstock for the sustainable synthesis of several added-value chemicals, including solketal-(2,2-dimethyl-1,3dioxolan-4-yl)methanol or 1,2-O-isopropylidene glycerol [1]. It is currently synthesized via ketalization reaction with acetone using homogeneous or 
heterogeneous acid catalysts [1,2]. Solketal has been successfully used to synthesize a variety of esters (fatty acid solketal esters-FASEs) used as potential fuel additives, lubricants, solvents, flavoring agents and plasticizers [3]. Moreover, solketal-based esters are promising emulsifier agents with excellent antimicrobial properties commonly used in food, cosmetics and personal care formulations $[4,5]$. Solketal presents a chiral center, thus increasing its interest in pharmaceutical and food industries [6-8].

Usually, solketal-based esters have been synthesized by esterification or transesterification reactions using classical homogeneous or heterogeneous catalysts $[2,3,5,9]$. However, these reactions require high temperature $\left(100-150^{\circ} \mathrm{C}\right)$ and long reaction-times to reach high conversions [3,9]. FASEs synthetized by using lipases as biocatalysts have gained special attention due to the mild reaction conditions and high biocatalyst selectivity $[4,7,10]$.

The enzymatic synthesis of FASEs has been described using fungal whole-cells [10,11], crude enzymatic extracts or immobilized lipases $[4,7,12]$. These studies have demonstrated the promising features of immobilized lipases in this reaction $[4,7,8]$. These biocatalysts have been prepared via immobilization of lipase from Pseudomonas fluorescens (PFL) via physical adsorption on multi-wall carbon nanotubes (MWCNTs) and Octyl-silica [7], and covalent attachment on functionalized MWCNTs and epoxy-functionalized mesoporous silica [8]. Other interesting studies have used lipase B from Candida antarctica (CALB) immobilized in water-in-oil microemulsions [4], and the commercial Novozym ${ }^{\circledR}$ 435 [12]—CALB immobilized on Lewatit VP OC 1600 [13].

In general, the synthesis of valuable esters, including FASEs, has been successfully performed using lipases immobilized by physical adsorption via interfacial activation on hydrophobic supports [7,13-18]. This immobilization protocol is based on the catalytic mechanism of lipases, called interfacial activation $[19,20]$. This method promotes selective adsorption (purification), hyperactivation and stabilization of the tridimensional lipase structures in their open conformation on hydrophobic surfaces [16-18,21], which allows preparing heterogeneous biocatalysts with high catalytic activity $[18,21-23]$.

The enzymatic synthesis of solketal palmitate was chosen because it is precursor in 1-monopalmitoyl glycerol (or 1-monopalmitin) synthesis via a simple acetal ring-opening using acid catalysts [12]. This important monoacylglycerol (MAG) has been used as a potential biomarker for type 2 diabetes mellitus [24], as modifier of the viscoelastic and sensory properties of processed cheese [25], and in the production of non-ionic surfactant vesicles for vaccines [26]. In this context, the aim of the present study was the optimization of the enzymatic synthesis of solketal palmitate by direct esterification of palmitic acid and solketal using heptane as solvent and evaluation of its in vitro antimicrobial activity against five pathogenic microorganisms (fungi and Gram-positive bacteria). The enzymes used in this paper were the lipases from Thermomyces lanuginosus-TLL [27], Pseudomonas fluorescens-PFL [28], and Candida rugosa-CRL [29-31]. They were selected due to their high catalytic activity, selectivity, and stability in ester synthesis using a broad number of natural and non-natural substrates. Heptane was selected as organic solvent in order to reduce the medium viscosity and, thus, to improve the dispersion of palmitic acid in the reaction medium, a long-chain fatty acid with melting point at $63^{\circ} \mathrm{C}$. To the best of our knowledge, this is the first study describing the enzymatic synthesis of a FASE using lipases immobilized on functionalized rice husk silica as biocatalysts and the evaluation of its antimicrobial activity against human pathogens.

The reaction is a thermodynamic controlled process, which means that the yields should be independent from the biocatalyst, except if the enzyme is inhibited or inactivated [32]. However, in this case the employed solketal is racemic and that can alter the final yields depending on the enzyme specificity for both solketal isomers $[7,8]$. The main problem found using the esterification reaction catalyzed by immobilized lipases is the water accumulation inside the biocatalysts, as this can produce the formation of a water phase that can lead to biocatalysts inactivation (due to the very low $\mathrm{pH}$ that this phase can reach in the presence of palmitic acid) or inhibition, if the substrate cannot penetrate through this water layer to reach the enzyme [33-37]. This may be solved using a hydrophobic support where water will be not retained [38-41]. As water is a product reaction, its 
removal from the reaction medium can shift the equilibrium in the synthesis direction, and this may be performed using molecular sieves [36,42-44]. However, this did not eliminate the risk of water phase formation inside the biocatalysts if the enzyme activity is very high [37], and it may have some negative effects if the essential water to keep the enzyme activity is removed $[45,46]$.

The immobilized biocatalysts were prepared as previously described using Octyl- $\mathrm{SiO}_{2}$, a silica-based hydrophobic support obtained from rice husks, an abundantly available agro-industrial waste. Its complete structural and textural characterization, as well as its use as support to prepare active biocatalysts in ester synthesis, have been primarily reported in a recent study [23]. After selecting the most active biocatalyst, solketal palmitate synthesis was optimized using a Central Composite Rotatable Design (CCRD), an ideal tool for process optimization, in order to evaluate the effect of biocatalyst concentration, reaction temperature and acid:alcohol molar ratio on the ester synthesis under fixed mechanical stirring ( $240 \mathrm{rpm})$ and reaction time $(15 \mathrm{~min})$. Subsequently, the effect of molecular sieve concentration, reactants concentration, and organic solvent on the reaction was examined under optimal conditions. Reusability tests have been checked. NMR analysis $\left({ }^{1} \mathrm{H}\right.$ NMR and ${ }^{13} \mathrm{C}$ NMR) was also performed to confirm the chemical structure of the synthesized ester.

\section{Results and Discussion}

\subsection{Immobilization of Different Lipases on $\mathrm{Octyl}-\mathrm{SiO}_{2}$}

In this study, three microbial lipase preparations were immobilized via interfacial activation on Octyl- $\mathrm{SiO}_{2}$ in order to select the most active biocatalyst in solketal palmitate synthesis. The reaction catalyzed by free crude lipase extracts was not performed, since immobilization processes promote better dispersion of lipase molecules in the reaction because it minimizes protein aggregation [41]. The immobilization parameters [47] of the different prepared biocatalysts are given in Table 1.

Table 1. Characterization of the heterogeneous biocatalysts prepared in this study and their performance in ester synthesis.

\begin{tabular}{|c|c|c|c|c|c|c|}
\hline \multirow{3}{*}{ Parameters } & \multicolumn{6}{|c|}{ Biocatalysts } \\
\hline & \multicolumn{2}{|c|}{ TLL } & \multicolumn{2}{|c|}{ PFL } & \multicolumn{2}{|c|}{ CRL } \\
\hline & $\begin{array}{l}\text { Crude } \\
\text { Extract }\end{array}$ & Immobilized & $\begin{array}{l}\text { Crude } \\
\text { Extract }\end{array}$ & Immobilized & $\begin{array}{l}\text { Crude } \\
\text { Extract }\end{array}$ & Immobilized \\
\hline Protein $(\mathrm{mg} / \mathrm{g})$ & $16.0^{\mathrm{a}}$ & $22.0 \pm 2.8$ & $24.5^{\mathrm{a}}$ & $19.4 \pm 2.0$ & $24.6^{a}$ & $21.2 \pm 2.2$ \\
\hline $\mathrm{HA}^{\mathrm{b}}(\mathrm{U} / \mathrm{g})$ & $27,302.4^{\mathrm{a}}$ & $656.0 \pm 23.9$ & $8611.2^{\mathrm{a}}$ & $532.9 \pm 42.9$ & $16,156.8^{\mathrm{a}}$ & $320.4 \pm 49.3$ \\
\hline $\mathrm{SA}^{\mathrm{c}}\left(\mathrm{U} / \mathrm{mg}_{\text {protein }}\right)$ & 1706.8 & $31.0 \pm 3.4$ & 351.5 & $27.5 \pm 3.6$ & 656.8 & $14.6 \pm 2.9$ \\
\hline$Y^{d}(\%)$ & NP & $62.6 \pm 2.1$ & NP & $63.8 \pm 1.7$ & $\mathrm{NP}$ & $76.1 \pm 1.3$ \\
\hline$t_{e} e^{e}(\min )$ & $\mathrm{NP}$ & 40 & $\mathrm{NP}$ & 50 & NP & 70 \\
\hline $\mathrm{P}^{\mathrm{f}}\left(\mathrm{mmol} / \mathrm{min} \cdot \mathrm{g}_{\text {biocat }}\right)$ & NP & 6.8 & NP & 4.6 & $\mathrm{NP}$ & 2.3 \\
\hline
\end{tabular}

These lipase preparations had different purity, enzyme concentration, and stabilizing agents in their formulations, as well as different features, including molecular mass, molecular diameter and activity [48]. However, as shown in Table 1, similar immobilized protein loading (around 20-22 $\mathrm{mg} / \mathrm{g}$ of support) has been obtained for CRL, PFL and TLL. On the other hand, these biocatalysts exhibited different activities in olive oil hydrolysis. The highest hydrolytic activity was observed for immobilized TLL $(656.0 \pm 23.9 \mathrm{U} / \mathrm{g})$, followed by PFL $(532.9 \pm 42.9 \mathrm{U} / \mathrm{g})$ and CRL $(320.4 \pm 49.3 \mathrm{U} / \mathrm{g})$. Comparing these values with the specific activity values of crude lipase extracts, a drastic decrease after immobilization procedure can be observed for all lipases tested, very likely due to substrate diffusional problems [21,41,49]. 


\subsection{Performance of the Different Biocatalysts in the Solketal Palmitate Synthesis}

The activity of the three lipase biocatalysts in solketal palmitate synthesis was determined (Table 1 and Figure 1). A linear profile of ester synthesis for conversion percentage values until $50 \%$ for all reaction was observed; both immobilized TLL and PFL displayed similar catalytic activities, which was higher than the activity of the immobilized CRL (Figure 1). Maximum conversion percentage of $63 \%$ for the reaction catalyzed with TLL and PFL were achieved after 40 and 50 min of reaction, respectively (Table 1 and Figure 1).

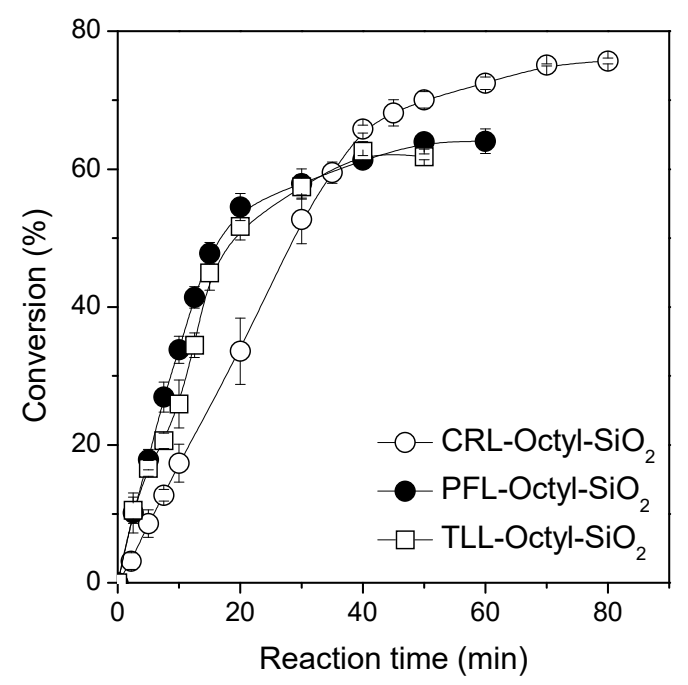

Figure 1. Effect of lipase source on the ester synthesis course. The reactions were performed at $40{ }^{\circ} \mathrm{C}$, $240 \mathrm{rpm}$, stoichiometric acid:alcohol molar ratio containing $0.2 \mathrm{M}$ of palmitic acid in heptane medium and biocatalyst concentration of 300 units of hydrolytic activity (U).

On the other hand, immobilized CRL gave the highest conversion percentage $(\approx 76 \%)$. However, the equilibrium was observed after $70 \mathrm{~min}$ of reaction. The yields should have been identical using the three enzymes, providing that all of them were able to recognize both solketal isomers. As in all cases, more than 50\% conversion was obtained; it may be assumed that all the enzymes recognized both enantioisomers of solketal. As CRL gave a much more lineal reaction courses than the other enzymes, it may be assumed that product inhibition or other kinetic problems reached a lower relevance for this enzyme than for the other enzymes [10], and that could be the explanation for these different yields obtained by the different biocatalysts. In Table 1, the productivity values for each reaction system are summarized. The maximum value was obtained for immobilized TLL ( $6.8 \mathrm{mmol} / \mathrm{min}$.g biocat $), 1.5-$ and 3-fold higher than for PFL-Octyl-SiO ${ }_{2}$ and CRL-Octyl-SiO ${ }_{2}$, respectively. Thus, even if the final steps of the process seem to be more complex using this biocatalyst, it was selected as heterogeneous biocatalyst in solketal palmitate synthesis.

\subsection{Ester Synthesis Optimization by CCRD}

The effect of reaction temperature, biocatalyst concentration and acid:alcohol molar ratio was evaluated by a full factorial design in CCRD mode to find the most important variables on the ester synthesis. These tests were performed under fixed palmitic acid concentration $(0.2 \mathrm{M})$ and continuous mechanical stirring of $240 \mathrm{rpm}$ to promote rapid access of reactant molecules from the reaction mixture to the biocatalyst. In Table 2, the coded and actual values of independent variables and predicted and experimental conversion percentage (response) are shown. 
Table 2. Central Composite Rotatable Design (CCRD) matrix for the analysis of the influence of independents variables on the ester synthesis catalyzed by TLL-Octyl- $\mathrm{SiO}_{2}$.

\begin{tabular}{cccccc}
\hline \multirow{2}{*}{ Runs } & \multicolumn{3}{c}{$\begin{array}{c}\text { Independent Variables } \\
\text { Coded (Actual) }\end{array}$} & $\begin{array}{c}\text { Conversion } \\
\mathbf{( \% )}\end{array}$ \\
\cline { 2 - 6 } & $\begin{array}{c}\text { Biocatalyst } \\
\mathbf{( U )}\end{array}$ & $\begin{array}{c}\text { Temperature } \\
\left({ }^{\circ} \mathbf{C}\right)\end{array}$ & $\begin{array}{c}\text { Acid:Alcohol } \\
\text { Molar Ratio }\end{array}$ & Experimental & Predicted $^{\mathbf{b}}$ \\
\hline 1 & $-1(383)$ & $-1(28)$ & $-1(1: 1.8)$ & $43.9 \pm 1.0$ & 33.7 \\
2 & $+1(1217)$ & $-1(28)$ & $-1(1: 1.8)$ & $70.0 \pm 0.5$ & 60.2 \\
3 & $-1(383)$ & $+1(52)$ & $-1(1: 1.8)$ & $73.0 \pm 1.1$ & 55.2 \\
4 & $+1(1217)$ & $+1(52)$ & $-1(1: 1.8)$ & $75.6 \pm 1.4$ & 81.7 \\
5 & $-1(383)$ & $-1(28)$ & $+1(1: 4.2)$ & $26.7 \pm 1.2$ & 33.7 \\
6 & $+1(1217)$ & $-1(28)$ & $+1(1: 4.2)$ & $55.7 \pm 1.4$ & 60.2 \\
7 & $-1(383)$ & $+1(52)$ & $+1(1: 4.2)$ & $62.5 \pm 1.6$ & 55.2 \\
8 & $+1(1217)$ & $+1(52)$ & $+1(1: 4.2)$ & $73.1 \pm 0.3$ & 81.7 \\
9 & $-1.68(100)$ & $0(40)$ & $0(1: 3)$ & $8.8 \pm 2.8$ & 23.4 \\
10 & $+1.68(1500)$ & $0(40)$ & $0(1: 3)$ & $75.9 \pm 0.6$ & 68.0 \\
11 & $0(800)$ & $-1.68(20)$ & $0(1: 3)$ & $50.1 \pm 1.9$ & 56.3 \\
12 & $0(800)$ & $+1.68(60)$ & $0(1: 3)$ & $85.0 \pm 0.5$ & 92.4 \\
13 & $0(800)$ & $0(40)$ & $-1.68(1: 1)$ & $43.8 \pm 0.5$ & 56.0 \\
14 & $0(800)$ & $0(40)$ & $+1.68(1: 5)$ & $61.4 \pm 0.6$ & 56.0 \\
15 & $0(800)$ & $0(40)$ & $0(1: 3)$ & $76.2 \pm 0.2$ & 74.4 \\
16 & $0(800)$ & $0(40)$ & $0(1: 3)$ & $75.9 \pm 0.6$ & 74.4 \\
17 & $0(800)$ & $0(40)$ & $0(1: 3)$ & $77.0 \pm 0.2$ & 74.4 \\
18 & $0(800)$ & $0(40)$ & $0(1: 3)$ & $76.5 \pm 0.9$ & 74.4 \\
\hline
\end{tabular}

${ }^{a}$ Biocatalyst concentration based on the hydrolytic activity (HA) of TLL-Octyl-SiO $2\left(\mathrm{HA}=656 \mathrm{U} / \mathrm{g}\right.$ - see Table 1); ${ }^{\mathrm{b}}$ values calculated according to Equation (1).

The conversion percentage ranged from $8.8 \% \pm 2.8 \%$ (run \#9) to $85.0 \% \pm 0.5 \%$ (run \#12) after 15 min of reaction. The experimental and predicted conversion percentage values were very similar, thus showing that the developed model can be successfully used for describing the relationship between independent variables and response.

According to the Pareto graph (Figure 2) obtained in the factorial design, the parameters mean, linear/quadratic terms for biocatalyst concentration $\left(x_{1}\right.$ and $\left.x_{1}{ }^{2}\right)$, linear term for reaction temperature $\left(x_{2}\right)$ and quadratic term for acid:alcohol molar ratio $\left(x_{3}{ }^{2}\right)$ were statistically significant at $95 \%$ confidence level, since they had a $p$-value below 0.05 (see Table 3). The regression coefficients for the significant parameters reported in Table 3 were used to express their effects on the conversion percentage, which was based on the coded values, as shown in Equation (1):

$$
Y(\%)=74.4+13.3 x_{1}-10.1 x_{1}^{2}+10.7 x_{2}-6.5 x_{3}^{2}
$$




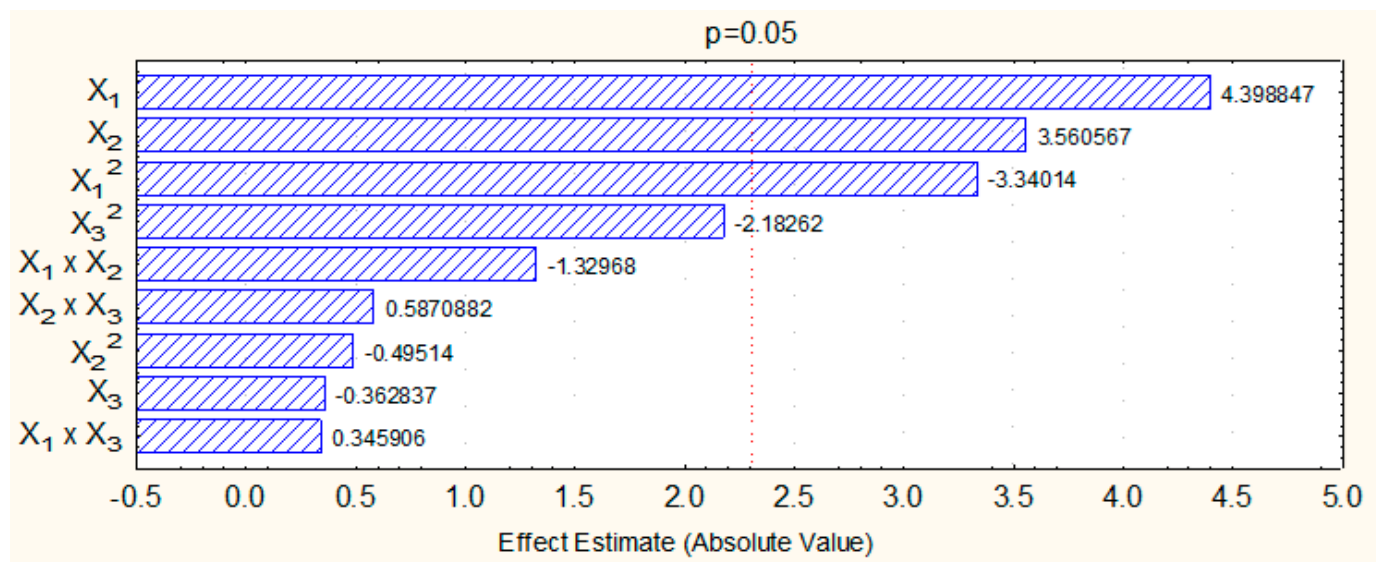

Figure 2. Pareto diagram showing the effect of independent parameters biocatalyst concentration $\left(x_{1}\right)$, reaction temperature $\left(x_{2}\right)$, and acid:alcohol molar ratio $\left(x_{3}\right)$ and their interactions on the conversion percentage in solketal palmitate synthesis.

ANOVA reveals that the developed model is adequate and sufficient to represent the actual relationships between reaction parameters and conversion percentage at a $p$-value $<0.05$, as shown in Table 3. A determination coefficient $\left(R^{2}\right)$ of 0.81 was obtained, thus indicating that $81 \%$ of the variability of responses could be explained by the developed model. The results summarized in Table 3 show that Fisher's F-test also showed significance due to the fact that the calculated F-value of regression (13.93) was almost 4.4-fold higher than tabulated $F$-value at 5\% significance level (3.18). Based on these results, 3D surface plots can be created for finding the optimal experimental conditions in order to maximize ester synthesis.

Table 3. Regression coefficients, standard errors and $p$-values and analysis of variance (ANOVA).

\begin{tabular}{|c|c|c|c|c|}
\hline & Parameter & Regression Coefficient & Standard Error & $p$-Values ${ }^{\text {a }}$ \\
\hline & Mean & 74.4 & \pm 0.18 & $3.5 \times 10^{-8}$ \\
\hline & $x_{1}$ & 13.3 & \pm 0.13 & $1.9 \times 10^{-6}$ \\
\hline & $x_{1}^{2}$ & -10.1 & \pm 0.13 & $4.5 \times 10^{-6}$ \\
\hline & $x_{2}$ & 10.7 & \pm 0.13 & $3.6 \times 10^{-6}$ \\
\hline & $x_{3}{ }^{2}$ & -6.5 & \pm 0.13 & $1.7 \times 10^{-5}$ \\
\hline \multicolumn{5}{|l|}{ ANOVA } \\
\hline $\begin{array}{l}\text { Source of } \\
\text { Variation }\end{array}$ & Sum of Squares & Degree of Freedom & Mean Square & F-test \\
\hline Regression & 5644.4 & 4 & 1411.1 & 13.93 \\
\hline Residual & 1316.8 & 13 & 101.3 & \\
\hline Lack of fit & 1316.17 & & & \\
\hline Pure error & 0.66 & & & \\
\hline Total & 6961.2 & 17 & & \\
\hline \multicolumn{5}{|c|}{$R^{2}=0.81 ; \mathrm{F}_{0.5 ; 4 ; 13}=3.18$} \\
\hline
\end{tabular}

$x_{1}, x_{2}$, and $x_{3}$ represent the variables biocatalyst concentration, reaction temperature, and acid:alcohol molar ratio, respectively; ${ }^{a}$ significant parameters at $95 \%$ confidence level.

Figure $3 \mathrm{~A}$ shows the effect of biocatalyst concentration and reaction temperature on the ester synthesis at a fixed acid:alcohol molar ratio at center point-1:3. It is possible to observe a strong influence of these variables on the reaction. A gradual increase in acid conversion from $8.8 \%$ to $85 \%$ by increasing the biocatalyst concentration from $100 \mathrm{U}$ to $800-900 \mathrm{U}$ (or from $2.5 \%$ to $20-23 \% \mathrm{wt}$. of TLL-Octyl- $\mathrm{SiO}_{2}$ per volume of reaction mixture) can be observed. On the other hand, a slight decrease in the conversion percentage from $85 \%$ to $\approx 75 \%$ was observed at a higher biocatalyst 
concentration-1500 U (or $2.3 \mathrm{~g}$ of TLL-Octyl-SiO ${ }_{2}$ ), that corresponds to $38 \%$ wt. of TLL-Octyl- $\mathrm{SiO}_{2}$ per volume of reaction mixture. This could be caused by the aggregation of the biocatalysts particles that will increase the diffusional problems or by the changes in the water activity caused by the increased concentration of both enzyme and support in the reaction medium. According to previous reports, an increase in reaction temperature increases the ester synthesis [22,49,50]. According to the obtained results in this paper, a significant and positive effect of reaction temperature on the reaction also observed and the highest conversion percentage was obtained above $55^{\circ} \mathrm{C}$. An increased temperature will reduce the high viscosity of the reaction mixture. Although reaction temperature and biocatalyst amount have demonstrated significant effects on the reaction, their interaction was not significant at a confidence level of $95 \%$.

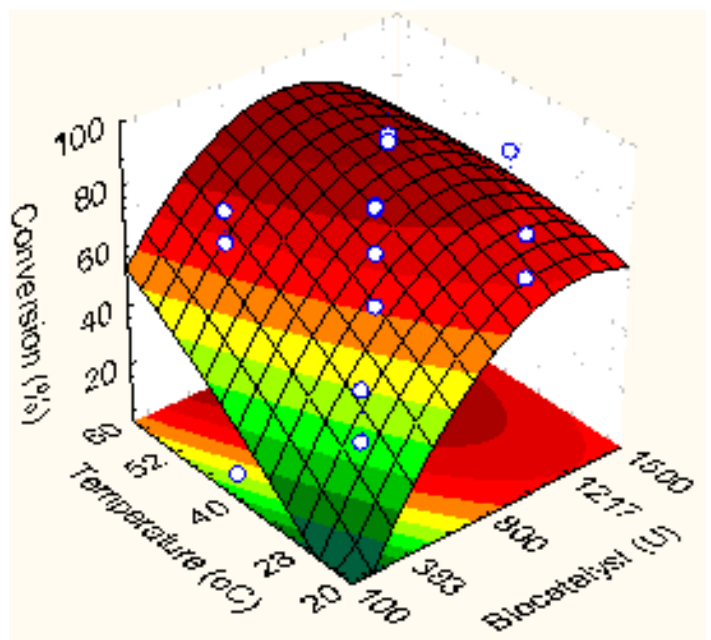

(A)

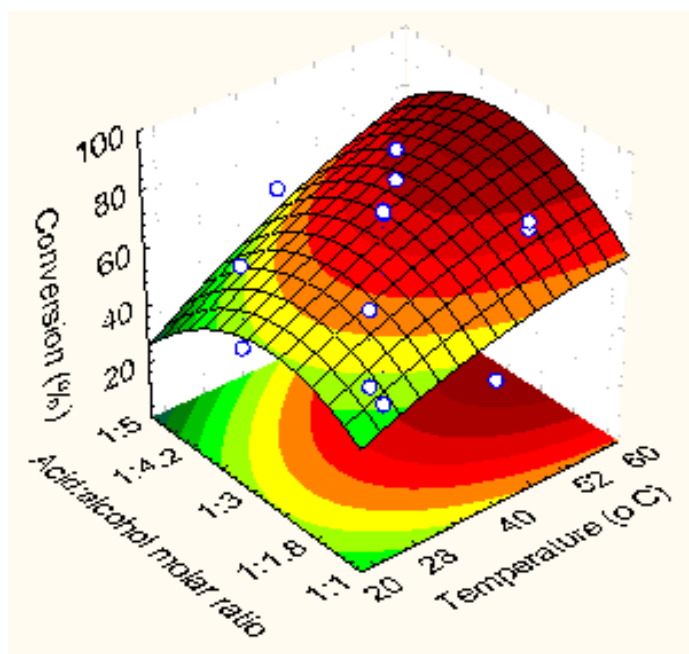

(B)

Figure 3. 3D surface and contour plots for ester synthesis. Effect of biocatalyst concentration and reaction temperature (A); and acid:alcohol molar ratio and reaction temperature (B) on the conversion percentage.

The effect of reaction temperature and acid:alcohol molar ratio on the reaction was also evaluated at a fixed biocatalyst concentration of $800 \mathrm{U}$ or $1.2 \mathrm{~g}$ of TLL-Octyl-SiO $\mathrm{S}_{2}$ (center point)—Figure 3B. In this study, palmitic acid was the limiting substrate of the reaction to avoid an excessive increase of the viscosity in the reaction mixture. That way, the effect of an excess of solketal concentration in the reaction was evaluated. As expected, a rise in reactants concentration in the reaction mixture leads to an increase in the ester formation [51]. However, high concentration of certain reactants can lead to deleterious effects on the biocatalyst, e.g., if it can distort the enzyme and produce enzyme inactivation, or just behaves like an inhibitor [51,52]. According to Figure 3B, initially, an excess of solketal concentration led to an improved ester synthesis and a maximum in conversion percentage was observed at an acid:alcohol molar ratio of 1:3. However, a further increase of solketal concentration led to a decrease in the conversion percentage due to possible inhibitory or inactivating effects of the alcohol [22,52]. In agreement with Figure 3A, maximum ester synthesis was obtained at the highest reaction temperature studied. The interaction reaction temperature and acid:alcohol molar ratio was not significant at $95 \%$ confidence level.

In order to validate the predicted model, further tests were performed under optimal experimental conditions. 3D surface plots analysis clearly show that maximum ester synthesis can be observed between 55 and $60^{\circ} \mathrm{C}$, acid:alcohol molar ratio of 1:3 and biocatalyst concentration ranging from 800 to 900 units (U). Thus, esterification reaction using an initial biocatalyst concentration of $900 \mathrm{U}$, and acid:alcohol molar ratio of $1: 3$ was conducted at $56{ }^{\circ} \mathrm{C}$ and $60{ }^{\circ} \mathrm{C}$ (runs \#1 and \#3-Table 4). Under such conditions, similar conversion values (around of $80 \%$ at $15 \mathrm{~min}$ of reaction) were obtained, thus showing that the reaction can be successfully performed at $56^{\circ} \mathrm{C}$. Subsequent runs were performed at 
a fixed initial biocatalyst concentration (900 U), however at stoichiometric acid:alcohol molar ratio (coded value $=-1$ ) and reaction temperatures of $56^{\circ} \mathrm{C}$ or $60^{\circ} \mathrm{C}$ (runs \#2 and \#4-Table 4). Similar conversion percentage was also obtained $(\approx 55 \%)$, thus confirming that the maximum conversion can be achieved at $56^{\circ} \mathrm{C}$. These results confirm also that an excess of solketal in the reaction mixture is required to achieve the maximum conversion. Afterwards, two runs were conducted at $56{ }^{\circ} \mathrm{C}$ (run \#5) and $60^{\circ} \mathrm{C}$ (run \#6 or run \#12 in Table 2), using a biocatalyst concentration of $800 \mathrm{U}$, and acid:alcohol molar ratio of 1:3, as shown in Table 4 . Under these conditions, conversion percentage of $\approx 85 \%$ was achieved, thus showing that a slight reduction of $100 \mathrm{U}$ (from 900 to $800 \mathrm{U}$ ) and $4{ }^{\circ} \mathrm{C}$ (from 56 to 60 ${ }^{\circ} \mathrm{C}$ ) did not have a strong effect on the reaction. It is possible to note a good correspondence between experimental and predicted conversion percentage values, thus confirming the satisfactory adequacy of the developed model to the experimental data. Thus, the optimal conditions to synthesize solketal palmitate were defined to be $20 \%$ wt. of TLL-Octyl-SiO${ }_{2}$ per volume of reaction mixture ( $800 \mathrm{U}$ or 1.2 $\mathrm{g}$ of TLL-Octyl-SiO$\left.{ }_{2}\right), 56^{\circ} \mathrm{C}$ and acid:alcohol molar ratio of 1:3.

Table 4. Validation of the developed CCRD by performing ester synthesis under optimal experimental conditions.

\begin{tabular}{|c|c|c|c|c|c|}
\hline \multirow{2}{*}{ Runs } & \multicolumn{3}{|c|}{$\begin{array}{l}\text { Independent Variables } \\
\text { Coded (Actual) }\end{array}$} & \multicolumn{2}{|c|}{$\begin{array}{c}\text { Conversion } \\
(\%)\end{array}$} \\
\hline & $\begin{array}{l}\text { Biocatalyst } \\
\text { (U) }\end{array}$ & $\begin{array}{c}\text { Temperature } \\
\left({ }^{\circ} \mathrm{C}\right)\end{array}$ & $\begin{array}{l}\text { Acid:Alcohol } \\
\text { Molar Ratio }\end{array}$ & Experimental & Predicted $^{\mathrm{a}}$ \\
\hline 1 & $+0.24(900)$ & $+1.34(56)$ & $0(1: 3)$ & $79.5 \pm 0.5$ & 91.3 \\
\hline 2 & $+0.24(900)$ & $+1.34(56)$ & $-1(1: 1)$ & $54.1 \pm 1.9$ & 84.8 \\
\hline 3 & $+0.24(900)$ & $+1.68(60)$ & $0(1: 3)$ & $81.1 \pm 1.4$ & 95.0 \\
\hline 4 & $+0.24(900)$ & $+1.68(60)$ & $-1(1: 1)$ & $56.6 \pm 2.4$ & 88.5 \\
\hline 5 & $+0(800)$ & $+1.34(56)$ & $0(1: 3)$ & $84.2 \pm 1.0$ & 88.7 \\
\hline $6^{b}$ & $+0(800)$ & $+1.68(60)$ & $0(1: 3)$ & $85.0 \pm 0.5$ & 92.4 \\
\hline
\end{tabular}

${ }^{a}$ Values calculated according to Equation (1); ${ }^{\text {b }}$ Experimental data obtained in run \#12 reported in Table 2.

\subsection{Effect of Reactants Concentration on the Reaction}

The increase of the volumetric productivity (ratio between ester amount and reactor volume) facilitates the isolation and purification of the reaction products [22,41,49,50]. In this set of experiments, the effect of reactants concentration on the ester synthesis using optimal acid:alcohol molar ratio of 1:3 was evaluated. The reactions were performed at different concentrations of palmitic acid $(0.2 \mathrm{M}, 0.5 \mathrm{M}$, $0.75 \mathrm{M}$ and $1 \mathrm{M}$ ) in heptane medium. The ester synthesis in a solvent-free system was also performed under the same experimental conditions (using an acid:alcohol molar ratio of 1:3). According to results shown in Figure 4, an increase in the reactants concentrations in the reaction mixture increased the reaction time necessary to attain the equilibrium from $20 \mathrm{~min}$ (for $0.2 \mathrm{M}$ of palmitic acid) to $360 \mathrm{~min}$ (solvent-free system). One of the reasons for this is the presence of more substrate molecules, but the time to reach equilibrium increased by an 18 -fold factor, while the concentration increased less than 9-fold. This is due to a decrease of the medium viscosity in the presence of heptane that improves the mass transfer of reactants. In fact, $66 \%$ conversion after $360 \mathrm{~min}$ of reaction was observed in a solvent-free system, which was a lower conversion and a time 2.4-fold higher than the reaction conducted at $1 \mathrm{M}$ of palmitic acid ( $83 \%$ conversion at $150 \mathrm{~min}$ of reaction). The productivity values for esterification reactions conducted with initial palmitic concentration of $0.2 \mathrm{M}, 0.5 \mathrm{M}, 0.75 \mathrm{M}, 1 \mathrm{M}$ and solvent-free system were determined as $7.3,3.7,3.3,4.6$, and $2.2 \mathrm{mmol} / \mathrm{min}$.g $g_{\text {biocat }}$, respectively. Although maximum productivity has been obtained at the lowest palmitic acid concentration, ester synthesis performed at $1 \mathrm{M}$ of palmitic acid is more interesting from an industrial point of view. Based on these results, ester synthesis at $1 \mathrm{M}$ of palmitic acid, with $3 \mathrm{M}$ of solketal and $28 \%(v / v)$ heptane, was chosen for further studies. 


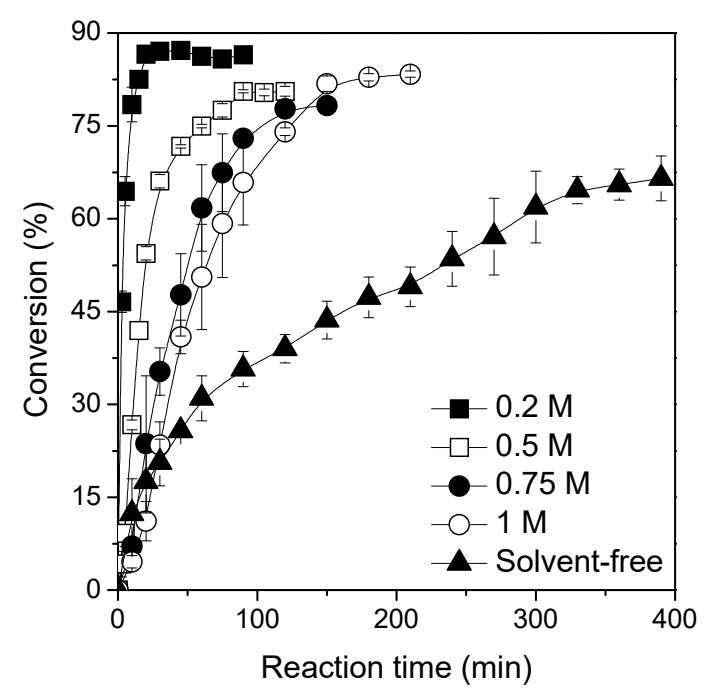

Figure 4. Effect of reactants concentration and organic solvent on the ester synthesis. The reactions were performed at $56^{\circ} \mathrm{C}, 240 \mathrm{rpm}$, acid:alcohol molar ratio 1:3, and biocatalyst concentration of $800 \mathrm{U}$ of activity by using TLL-Octyl- $\mathrm{SiO}_{2}$ as biocatalyst.

\subsection{Effect of Molecular Sieves Concentration on the Reaction}

One of the products of the esterification reaction is water $[33,34,43]$. This can generate some problems, like the accumulation inside the biocatalyst particle [35-37,43]. Moreover, as this reaction is a thermodynamically controlled synthesis, water removal from the system will shift the equilibrium on the desired direction $[39,40,44]$. Thus, its concentration in the reaction should be strictly controlled to enhance synthesis yield $[36,44,53]$. For this goal, the addition of dehydrating strategies, including molecular sieves [36,44,54], pervaporation [53], and bubbling dried air [44] have been assayed. The most popular strategy to control water concentration in esterification reactions consists in the use of molecular sieves due to their high capacity to adsorb water molecules and their reusability $[36,41,44,54]$. Thus, the addition of molecular sieves in the reaction medium has been evaluated in the range from $0 \%$ to $20 \% \mathrm{~m} / \mathrm{v}$. As it can be seen in Figure 5, a slight improvement in the initial reaction rates by using molecular sieves at different concentrations can be observed, mainly for the esterification reaction performed at the lowest molecular sieves concentration $(5 \% \mathrm{~m} / \mathrm{v})$. Under such conditions, a conversion percentage of $75 \%$ at $90 \mathrm{~min}$ of reaction was obtained while, in the absence of dehydrating agent, it was only $55 \%$. However, no influence of molecular sieves on the reaction may be observed at equilibrium and a similar conversion percentage of $83 \%$ was observed within 150 min of reaction, thus making the addition of molecular sieves to the reaction medium unnecessary $[49,50,54-56]$. 


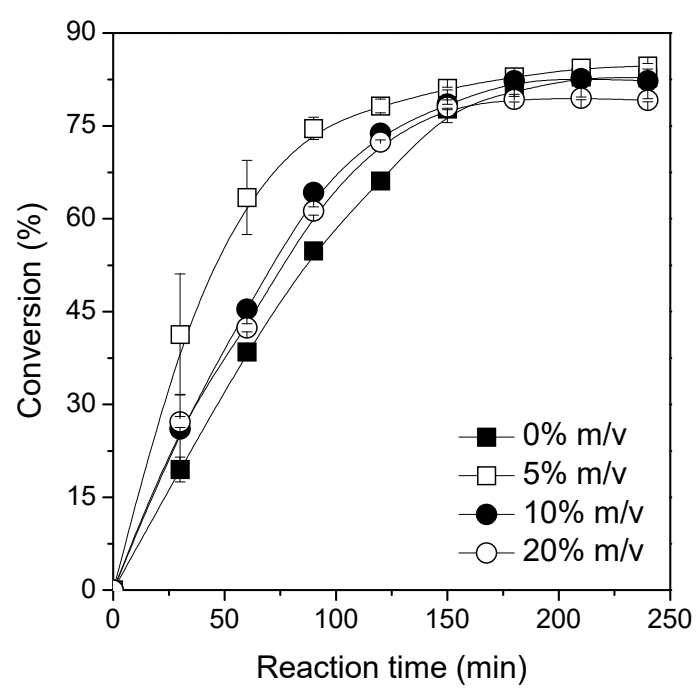

Figure 5. Effect of molecular sieves concentration on the ester synthesis. The reactions were performed at $56{ }^{\circ} \mathrm{C}, 240 \mathrm{rpm}$, acid:alcohol molar ratio 1:3, and biocatalyst concentration of $800 \mathrm{U}$ of activity by using TLL-Octyl-SiO 2 as biocatalyst.

\subsection{Biocatalyst Reusability Study}

The reusability of TLL-Octyl- $\mathrm{SiO}_{2}$ was studied under optimal conditions, in reaction batches of 150 min each (Figure 6). The catalytic activity of the biocatalyst remained practically unaltered in the first four batches, and after that point a slight decrease of its activity could be detected.

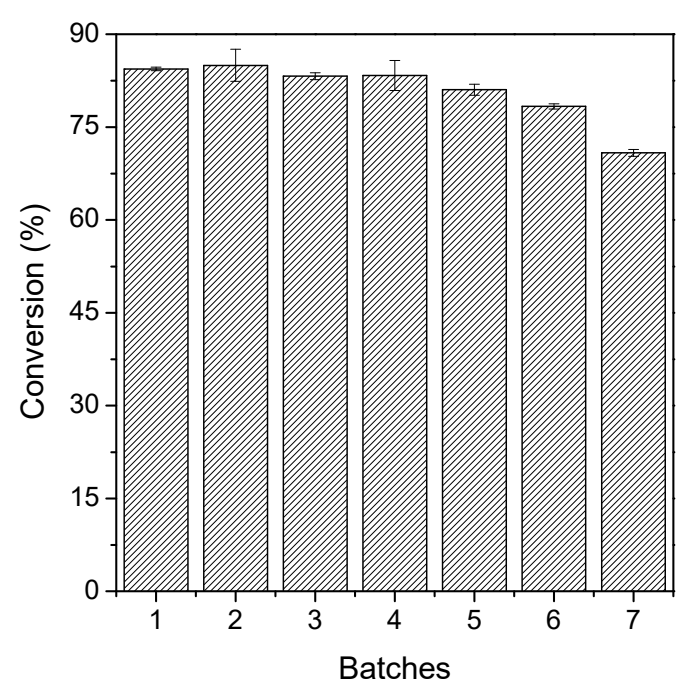

Figure 6. Reusability tests of TLL-Octyl-SiO 2 after seven consecutive batches of ester synthesis of each $150 \mathrm{~min}$ each in a heptane medium. The reactions were performed at $56^{\circ} \mathrm{C}, 240 \mathrm{rpm}$, acid:alcohol molar ratio 1:3, and biocatalyst concentration of $800 \mathrm{U}$.

After seven consecutive batches, the biocatalyst retained $87 \%$ of its original activity. This slight decrease in activity may be due to lipase inactivation (the employed temperature was $56^{\circ} \mathrm{C}$ ), enzyme release from the support-a combination of high temperature and detergent molecules (solketal palmitate) [17], and/or accumulation of water or solketal molecules on the biocatalyst surface, thus leading to formation of a hydrophilic layer that restricts the partition of palmitic acid molecules to its microenvironment $[33,34,43]$. 


\subsection{NMR Analysis of the Synthesized Ester}

The purified ester was a viscous liquid at room temperature and its molecular formula is $\mathrm{C}_{22} \mathrm{H}_{42} \mathrm{O}_{4}$ (Figure 7), with a molecular mass of $310 \mathrm{~g} / \mathrm{mol}$. According to Table 5, Distortionless Enhancement by Polarization Transfer (DEPT-135), Heteronuclear Single Quantum Coherence (HSQC) and Heteronuclear Multiple Bond Correlation (HMBC) spectra of the synthesized ester showed carbon signals that correspond to three methyl groups $\mathrm{C}-16, \mathrm{C} 23^{*}$ and $\mathrm{C} 24^{*}\left(\delta_{\mathrm{C}} 14.2,26.7\right.$ and 25.4 , respectively), 13 methylenes C-2, C-3, C4-C13, C-14 and C-15 $\left(\delta_{C} 34.1,24.9,29.1-29.7,22.7\right.$, respectively), and two oxigenated methylenes $C-17$ and $C-22$ at 64.5 and $66.3 \mathrm{ppm}$, one oxigenated methine $C-18\left(\delta_{C} 73.7\right)$ and two quaternary carbons, $\mathrm{C}-1$ a carbonyl group $\left(\delta_{\mathrm{C}} 173.8\right)$ and $\mathrm{C}-20 \mathrm{a} \mathrm{sp}^{3}$ carbon $\left(\delta_{\mathrm{C}} 109.8\right)$.

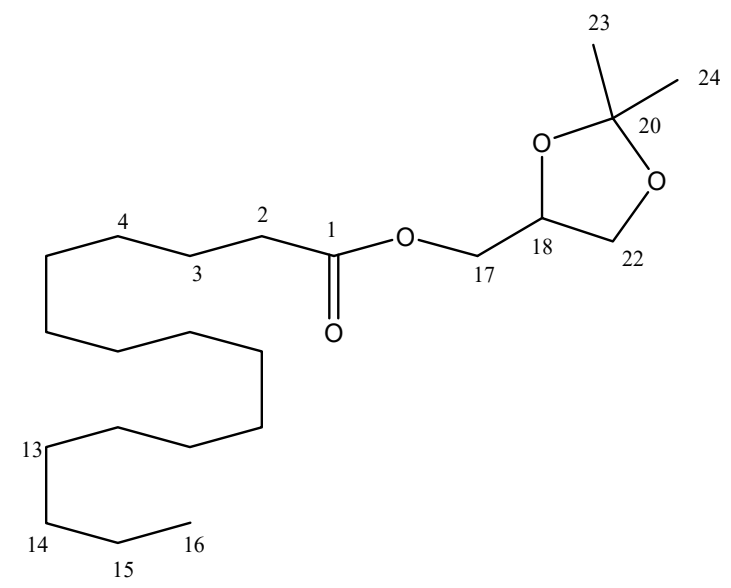

Figure 7. Chemical structure of solketal palmitate.

Table 5. ${ }^{1} \mathrm{H}$ and ${ }^{13} \mathrm{C}$ NMR data of solketal palmitate.

\begin{tabular}{cccc}
\hline Position & $\begin{array}{c}\boldsymbol{\delta}^{\mathbf{1 3}} \mathbf{C} \\
\left(\mathrm{CDCl}_{3}\right)\end{array}$ & $\begin{array}{c}\boldsymbol{\delta}^{\mathbf{1}} \mathbf{H}(\mathbf{m}, \mathbf{J}-\mathbf{H z}) \\
\left(\mathrm{CDCl}_{3}\right)\end{array}$ & HMBC $^{\mathbf{a}}$ \\
\hline 1 & $173.8(\mathrm{C}=\mathrm{O})$ & & $4.09 ; 4.11 ; 2.34 ; 1.62$ \\
20 & $109.8(\mathrm{C})$ & & $3.71 ; 4.05 ; 4.09 ; 1.37 ; 1.43$ \\
18 & $73.7(\mathrm{CH})$ & $4.32(\mathrm{~m})$ & $3.71 ; 4.09 ; 4.11$ \\
22 & $66.3\left(\mathrm{CH}_{2}\right)$ & $3.71 ; 4.05$ & $4.09 ; 4.15$ \\
17 & $64.5\left(\mathrm{CH}_{2}\right)$ & $4.11 ; 4.09(\mathrm{~m})$ & $3.71 ; 4.09 ; 4.11$ \\
2 & $34.1\left(\mathrm{CH}_{2}\right)$ & $2.34(\mathrm{t}, 6)$ & 1.62 \\
14 & $31.9\left(\mathrm{CH}_{2}\right)$ & $1.25(\mathrm{~m})$ & $1.25 ; 0.87$ \\
& $29.7\left(\mathrm{CH}_{2}\right)$ & $1.25(\mathrm{~m})$ & \\
& $29.6\left(\mathrm{CH}_{2}\right)$ & $1.25(\mathrm{~m})$ & \\
& $29.5\left(\mathrm{CH}_{2}\right)$ & $1.25(\mathrm{~m})$ & 1.37 \\
& $29.4\left(\mathrm{CH}_{2}\right)$ & $1.25(\mathrm{~m})$ & 1.43 \\
& $29.3\left(\mathrm{CH}_{2}\right)$ & $1.25(\mathrm{~m})$ & 2.34 \\
23 & $29.1\left(\mathrm{CH}_{2}\right)$ & $1.25(\mathrm{~m})$ & $0.87 ; 1.25$ \\
24 & $26.7\left(\mathrm{CH}_{3}\right)$ & $1.43(\mathrm{~s})$ & 1.25 \\
\hline 3 & $25.4\left(\mathrm{CH}_{3}\right)$ & $1.37(\mathrm{~s})$ & \\
\hline
\end{tabular}

${ }^{1} \mathrm{H}$ NMR analysis of solketal palmitate displayed signals due to three methyl groups at $\delta \mathrm{H} 0.87$ $(3 \mathrm{H}, \mathrm{t}, J=6 \mathrm{~Hz}, \mathrm{H}-16), 1.37(3 \mathrm{H}, \mathrm{s}, \mathrm{H}-24)$ and $1.43(3 \mathrm{H}, \mathrm{s}, \mathrm{H}-23)$, two oxigenated methylene at $\delta \mathrm{H} 4.09$ and $4.11(2 \mathrm{H}, \mathrm{m}, \mathrm{H}-17)$ and at $\delta \mathrm{H} 3.71$ and $4.05(2 \mathrm{H}, \mathrm{m}, \mathrm{H}-22)$, one sp ${ }^{3}$ oxigenated methine at $\delta \mathrm{H} 4.32$ $(1 \mathrm{H}, \mathrm{m}, \mathrm{H}-18)$ and 14 methylene groups at $\delta \mathrm{H} 2.34(2 \mathrm{H}, \mathrm{t}, J=6.0 \mathrm{~Hz}, \mathrm{H}-2), 1.25(2 \mathrm{H}, \mathrm{m}, \mathrm{H}-14), 1.62(2 \mathrm{H}$, 
m, H-3), 1.25 (2H, m, H-15), 1.25 (20H, m, H4-H14). The HMBC correlations from H-17 ( $\delta \mathrm{H} 4.09$ and $4.11)$ to $C-1$ ( $\delta \mathrm{C} 173.8$ - carbonyl) confirm the enzymatic synthesis of solketal palmitate.

\subsection{In Vitro Antimicrobial Activity Study}

The in vitro antimicrobial activity of the solketal palmitate synthesized in this study against two Gram-positive bacteria and three fungi strains are summarized in Table 6. According to Holetz et al. [57], a compound is considered to have a good antimicrobial activity when presenting MIC values lower than $100 \mu \mathrm{g} / \mathrm{mL}$, a moderate activity from 100 to $500 \mu \mathrm{g} / \mathrm{mL}$, a low activity from 500 to 1000 $\mu \mathrm{g} / \mathrm{mL}$ and they are considered to be inactive when presenting MIC above $1000 \mu \mathrm{g} / \mathrm{mL}$. Based on this scale, the synthesized ester demonstrated a moderate activity against C. albicans and C. parapsilosis, with a MIC value of $200-400 \mu \mathrm{g} / \mathrm{mL}$ for both strains. In addition, MMC values were $>400 \mu \mathrm{g} / \mathrm{mL}$ for all evaluated strains, thus indicating that the ester shows bacteriostatic and fungistatic action. These results could be due to its high hydrophobicity, thus improving its ability to interact with cell membranes and/or to penetrate through the cell membrane of these pathogens [58]. These results are in accordance with a previous study regarding the use of solketal-based esters as potential antimicrobial agents [5].

Table 6. Antimicrobial activity of solketal palmitate against several pathogens.

\begin{tabular}{ccccc}
\hline \multirow{2}{*}{ Pathogens } & \multicolumn{2}{c}{ Solketal Palmitate } & \multicolumn{2}{c}{ Fluconazol } \\
\cline { 2 - 5 } & $\begin{array}{c}\text { MIC } \\
(\mu \mathrm{g} / \mathrm{mL})\end{array}$ & $\begin{array}{c}\text { MMC } \\
(\mu \mathrm{g} / \mathbf{m L})\end{array}$ & $\begin{array}{c}\text { MIC } \\
(\mu \mathrm{g} / \mathrm{mL})\end{array}$ & $\begin{array}{c}\text { MMC } \\
(\mu \mathrm{g} / \mathrm{mL})\end{array}$ \\
\hline C. albicans & $200-400$ & $>400$ & $0.312-0.625$ & $20-40$ \\
C. tropicalis & $>400$ & $>400$ & $2.5-5.0$ & $>400$ \\
C. parapsilosis & $200-400$ & $>400$ & $2.5-5.0$ & $>400$ \\
\hline \multicolumn{2}{c}{ S. aureus } & $>400$ & $>400$ & \multicolumn{2}{c}{ Amoxicillin } \\
\hline L. monocytogenes & $>400$ & $>400$ & $0.078-0.156$ & $>400$ \\
\hline
\end{tabular}

\section{Materials and Methods}

\subsection{Materials}

TLL, CRL and PFL were purchased from Sigma-Aldrich (St. Louis, MO, USA) and used as received. Rice husks were acquired from Arroz Rei Ouro Ltda. (Itajubá, MG, Brazil). Triethoxy(octyl)silane (OCTES), palmitic acid and solketal were also purchased from Sigma-Aldrich. Molecular sieve UOP type $3 \AA$ (form of rod, and size of 1/16 in) was purchased from Fluka Analytical (St. Louis, MO, USA). Mueller-Hinton agar (MHA), Sabouraund dextrose agar (SDA), Roswell Park Memorial Institute (RPMI) medium, resazurin sodium salt powder, amoxicillim and fluconazole were acquired from HiMedia Laboratories (Mumbai, MH, India). All other reagents and solvents were of analytical grade acquired from Synth ${ }^{\circledR}$ (São Paulo, SP, Brazil).

\subsection{Lipase Immobilization Procedure}

Octyl- $\mathrm{SiO}_{2}$ was prepared by functionalization of rice husk silica with OCTES as reported elsewhere [23]. The immobilization of lipases by interfacial activation on Octyl- $\mathrm{SiO}_{2}$ was performed using an initial protein loading of $40 \mathrm{mg} / \mathrm{g}$ to achieve the maximum enzyme loading possible [23]. 22 $\mathrm{mL}$ of crude TLL or $16 \mathrm{~g}$ of crude PFL or CRL were dispersed in $5 \mathrm{mM}$ sodium phosphate at $\mathrm{pH} 7.0$ (168 mL for TLL and $190 \mathrm{~mL}$ for PFL and CRL), followed by adding $10 \mathrm{~g}$ of dry support previously incubated at $50{ }^{\circ} \mathrm{C}$ by $24 \mathrm{~h}$. The suspensions were incubated in an orbital shaker with a water bath for temperature control at $25^{\circ} \mathrm{C}, 200 \mathrm{rpm}$ and $18 \mathrm{~h}$. Afterwards, the suspensions were filtered under vacuum with Whatman ${ }^{\circledR}$ grade 41 filter paper and washed with distilled water, followed by storage of 
the prepared biocatalysts at $4{ }^{\circ} \mathrm{C}$ for $24 \mathrm{~h}$. The immobilization process was monitored by determining the protein concentration by Bradford's method [59], and the catalytic activity by olive oil emulsion hydrolysis in the immobilization supernatant and a reference under identical conditions [21] (which kept its activity unaltered during the whole process). One unit (1 U) of hydrolytic activity was defined as the amount of lipase necessary to release $1 \mu \mathrm{mol}$ of free fatty acid per min of reaction at $\mathrm{pH} 8.0$ and $37^{\circ} \mathrm{C}[21]$.

\subsection{Solketal Palmitate Synthesis}

The esterification of palmitic acid and solketal was conducted in $100 \mathrm{~mL}$ screw-capped glass bottles containing $6 \mathrm{~mL}$ of reaction mixture. Palmitic acid was fully dissolved in the reaction mixtures (solvent or solvent-free systems) under all experimental conditions tested in this work. Subsequently, the heterogeneous biocatalysts prepared were added to reaction mixtures, followed by incubation in an orbital shaker water bath with temperate control and a fixed mechanical stirring ( $240 \mathrm{rpm})$. Aliquots $(25 \mu \mathrm{L})$ from the reaction mixture were periodically withdraw, diluted in $10 \mathrm{~mL}$ of hydrous ethanol solution $(95 \% \mathrm{~m} / \mathrm{m})$ and titrated using $35 \mathrm{mM}$ sodium hydroxide using phenolphthalein as the $\mathrm{pH}$ indicator to determine the conversion percentage $(Y)$, as shown in Equation (2) [21]. All assays were performed with two independent replications.

$$
Y(\%)=\left(\frac{P A_{0}-P A_{t}}{P A_{0}}\right) \times 100
$$

where: $P A_{0}$ is the initial palmitic acid $(\mathrm{M})$, and $P A_{t}$ is the residual palmitic acid concentration at a certain time $t$ of reaction $(\mathrm{M})$.

\subsubsection{Effect of Lipase Source}

To determine the best biocatalysts in the ester synthesis, reactions were conducted using the three immobilized enzymes at a biocatalyst concentration of $300 \mathrm{U}$ of hydrolytic activity (that corresponds to $0.46 \mathrm{~g}$ of TLL-Octyl-SiO${ }_{2}, 0.56 \mathrm{~g}$ of PFL-Octyl-SiO${ }_{2}$ and $0.94 \mathrm{~g}$ of CRL-Octyl-SiO${ }_{2}$ ), stoichiometric acid:alcohol molar ratio and $0.2 \mathrm{M}$ palmitic acid in heptane at $40{ }^{\circ} \mathrm{C}$ and employing a mechanical stirring of $240 \mathrm{rpm}$. The productivity $(P-\mathrm{mmol} / \mathrm{min}$. gbiocat $)$ was determined as shown in Equation (3):

$$
P=\frac{P A_{e}}{t_{e} \times C_{\text {biocat }}}
$$

where: $P A_{e}$ is the consumed palmitic acid concentration at equilibrium $(\mathrm{mmol}), t_{e}$ is the reaction time at equilibrium ( $\mathrm{min}$ ), and $C_{\text {biocat. }}$ is the biocatalyst concentration in the reaction mixture (g).

\subsubsection{Ester Synthesis Optimization by CCRD}

The effect of three independent variables such as reaction temperature $\left(20-60{ }^{\circ} \mathrm{C}\right)$, biocatalyst concentration (100-1,500 U of hydrolytic activity using TLL-Octyl-SiO${ }_{2}$ as biocatalyst), and acid:alcohol molar ratio (1:1-1:5) was investigated by a three factor-five level CCRD consisting of 18 assays performed in a random order with six axial points, eight factorial points and four center points. The levels of each variable were chosen after preliminary tests performed in our lab (not published results). The esterification reactions were performed at fixed concentration of $0.2 \mathrm{M}$ of palmitic acid, mechanical stirring of $240 \mathrm{rpm}$, and $15 \mathrm{~min}$ of reaction. For the statistical analysis, the actual values were coded $\left(X_{i}\right)$ according to Equation (4):

$$
X_{i}=\frac{x_{i}-x_{0}}{\Delta x_{i}} \therefore i=1,2,3
$$

where $x_{i}$ is the actual value of the independent variable, $x_{0}$ is the actual value of the independent variable at the center point, and $\Delta x_{i}$ is the step change value of the independent variable $i$ that corresponds to variation of a unit for the dimensionless value of the variable $i$. 
In this set of experiments, the conversion percentage was considered as the dependent variable (response). After performing the runs, the experimental results were analyzed at $95 \%$ confidence level using the software Statistica version 5.0 (StatSoft Inc., Tulsa, OK, USA) to develop three-dimensional (3D) surface plots and quadratic equation-Equation (5).

$$
Y(\%)=a_{0}+\sum_{i=1}^{n} a_{i} x_{i}+\sum_{i=1}^{n} a_{i i} x_{i}{ }^{2}+\sum_{i=1}^{n-1} \sum_{j=i+1}^{n} a_{i j} x_{i} x_{j}+e
$$

where $Y$ is the predicted conversion percentage; $n$ is the number of factors, $x_{i}$ and $x_{j}$ are the coded independent variables; $a_{0}, a_{i}, a_{i i}$, and $a_{i j}$ are the regression coefficients of intercept, linear, quadratic, and interaction terms, respectively; $i$ and $j$ are the index numbers for each variable; and $e$ is the error of the model.

The statistical significance of the regression coefficients was determined by using Student's $t$-test and the developed model equation was determined by Fisher's F-test. The analysis of variance (ANOVA) and determination coefficient $\left(R^{2}\right)$ were used to check the adequacy of the developed model. In this study, 3D surfaces were plotted in order to find the optimal conditions for the validation of the model by performing esterification reactions under optimal predicted conditions. These experimental results were compared to the theoretical values predicted by the developed model (Equation (4)).

\subsubsection{Effect of Reactants Concentration}

Under the optimal conditions found above, the effect of reactants concentration varying from $0.2 \mathrm{M}$ to $1 \mathrm{M}$ of palmitic acid in heptane medium was examined. The ester synthesis conducted in a solvent-free system was also performed under similar conditions in order to check the effect of heptane on the reaction. The reactions were performed at an acid:alcohol molar ratio of 1:3.

\subsubsection{Effect of Molecular Sieve Concentration}

The effect of molecular sieve concentration, varying from $0 \%$ to $20 \% \mathrm{~m} / \mathrm{v}$ of reaction mixture was subsequently studied under the optimal experimental conditions found in Section 3.3.3. The molecular sieves were previously incubated in a furnace at $250{ }^{\circ} \mathrm{C}$ for $4 \mathrm{~h}$ to remove all water traces and other volatile compounds, followed by cooling to room temperature in closed flasks before use.

\subsubsection{Biocatalyst Reusability Study}

The reusability of TLL-Octyl- $\mathrm{SiO}_{2}$ was determined by measuring its ability to catalyze several consecutive batches of ester synthesis (150 min each) under optimal conditions (Section 3.3.4). After each reaction batch, the biocatalyst was recovered by filtration under vacuum, washed with cold hexane to remove any unconverted reactants and/or product molecules and added to a fresh reaction mixture to catalyze the next reaction batch. The conversion percentage was determined after $150 \mathrm{~min}$ of reaction.

\subsection{Ester Purification}

After the reaction, the supernatant was recovered from the reaction mixture by filtration under vacuum. Subsequently, it was incubated overnight at $4{ }^{\circ} \mathrm{C}$ for precipitation of unconverted palmitic acid, followed by a new filtration under vacuum with Whatman ${ }^{\circledR}$ grade 41 filter paper. The ester purification from the resulting reaction mixture was performed using a pre-coated cartridge of silica gel (Waters Sep-Pak ${ }^{\circledR}$ Vac-10 g). Increasing polarity gradient was used as eluent-hexane:ethyl acetate $(9: 1,8: 2,7: 3,1: 1 v / v)$. The fractions containing the ester were collected and the solvents were evaporated in a rotary evaporator under vacuum at $50{ }^{\circ} \mathrm{C}$. The resulting solution was then incubated overnight at room temperature in anhydrous sodium sulfate $(20 \% \mathrm{~m} / \mathrm{v})$ to remove water traces. Following this, the purification process was monitored by TLC using silica gel 60 F254 (Macherey-Nagel GmbH \& 
Co., Easton, PA, USA). The mobile phase consisted of a mixture of hexane/ethyl acetate/acetic acid in a 90:10:1 (v:v:v) ratio. The spots were detected using phosphomolybdic acid ethanolic solution at $10 \% \mathrm{~m} / \mathrm{v}$.

\subsection{NMR Analysis}

${ }^{1} \mathrm{H}(300 \mathrm{MHz})$ and ${ }^{13} \mathrm{C}(75 \mathrm{MHz})$ NMR spectra were acquired on a Bruker AC300 spectrometer (Bruker BioSpin, Rheinstetten, Germany). $12 \mathrm{mg}$ of the purified ester was dissolved in $0.6 \mathrm{~mL}$ of $\mathrm{CDCl}_{3}$ and it was placed in a $5 \mathrm{~mm}$ diameter NMR tube.

\subsection{In Vitro Antimicrobial Activity Tests}

The in vitro antimicrobial activity of the purified ester was studied according to standard methodologies from Clinical and Laboratory Standards Institute-CLSI [60] for yeasts, and CLSI [61] for bacteria, with slight modifications. The test was performed in a MHA medium for activity against Staphylococcus aureus (ATCC 6538) and Listeria monocytogenes (ATCC 4555), and in a RPMI medium for activity against Candida albicans (ATCC 10231), Candida tropicalis (ATCC 750) and Candida parapsilosis (ATCC 2209). The ester was dissolved in $125 \mu \mathrm{L}$ anhydrous ethanol $(8 \mathrm{mg} / \mathrm{mL})$ and it was placed in 96-well plates under serial dilutions (400-3125 $\mu \mathrm{g} / \mathrm{mL}$ ). The inoculum was prepared as a suspension that was standardized in a spectrophotometer at $660 \mathrm{~nm}$ and $75 \%$ transmittance, corresponding to a 1.5 $\times 10^{8}$ colony forming units (CFU) per mL of medium. Amoxicillin $(10-0.078 \mu \mathrm{g} / \mathrm{mL})$ and fluconazole $(80-0.625 \mu \mathrm{g} / \mathrm{mL})$ were used as positive controls. The microplates were incubated at $37^{\circ} \mathrm{C}$ within $24 \mathrm{~h}$. Resazurin solution $(0.2 \% \mathrm{~m} / \mathrm{v})$ was added to each well in order to indicate microorganism viability for the minimum inhibitory concentration (MIC) determination [62]. Sterility controls of the culture medium, inocula, and ethanol were prepared as negative controls. Regarding the minimum microbicial concentration (MMC) determination, an aliquot of $25 \mu \mathrm{L}$ was removed from each well and applied to a Petri dish surface containing MHA medium for bacteria, and SDA medium for yeasts, followed by incubating at $37^{\circ} \mathrm{C}$ by $24 \mathrm{~h}$.

\section{Conclusions}

In this study, an optimized process for the sustainable synthesis of solketal palmitate by direct esterification has been successfully developed. The application of solketal to synthesize valuable esters may be a promising route for the valorization of glycerol, a byproduct from the biodiesel industry. Under optimal experimental conditions, maximum conversion of $83 \%$ has been obtained after $150 \mathrm{~min}$ of reaction catalyzed by TLL-Octyl- $\mathrm{SiO}_{2}$. This biocatalyst retained $87 \%$ of its original activity after seven consecutive batches, thus demonstrating its promising use in ester synthesis. The purified ester could be potentially applied in food and pharmaceutical formulations due to its antifungal activity and bacteriostatic/fungistatic action.

Author Contributions: Conceptualization, R.F.-L, E.C.C. and A.A.M.; methodology, A.A.M. and J.H.H.L.; validation, P.A.M.-O., R.S.G., and O.C.G.; formal analysis, J.H.H.L., E.C.C. and A.A.M.; investigation, P.A.M.-O., R.S.G., and O.C.G.; resources, P.A.M.-O., R.S.G., and O.C.G.; data curation, P.A.M.-O., E.C.C. and A.A.M.; writing-original draft preparation, E.C.C. and A.A.M.; writing-review and editing, R.F.-L. and A.A.M.; visualization, P.A.M.-O., R.S.G., O.C.G., J.H.H.L., R.F.-L., E.C.C. and A.A.M.; supervision, E.C.C. and A.A.M.; project administration, A.A.M.; funding acquisition, R.F.-L. and A.A.M. All authors have read and agreed to the published version of the manuscript.

Funding: This research was funded by Fundação de Amparo à Pesquisa do Estado de Minas Gerais (FAPEMIG), grant number APQ-02196-15; Conselho Nacional de Desenvolvimento Científico e Tecnológico (CNPq), grant number 404929/2016-8; and Spanish Ministerio de Ciencia e Innovación, grant number CTQ2017-86170-R.

Acknowledgments: This study was financed in part by the Coordenação de Aperfeiçoamento de Pessoal de Nível Superior-Brasil (CAPES)_Finance Code 001. P.A.M.-O. thanks the CNPq, R.S.G. thanks the CAPES and O.C.G. thanks the Program PEC-PG (Programa de Estudantes-Convênio de Pós-Graduação) of the CAPES/CNPq for their student fellowships. A.A.M. thanks the CNPq for the research fellowship (PQ-2 CA EQ, grant number 301355/2017-7). The help and suggestions from Ángel Berenguer (Departamento de Química Inorgánica) are gratefully recognized. 
Conflicts of Interest: The authors declare no conflict of interest.

\section{References}

1. Nanda, M.R.; Zhang, Y.; Yuan, Z.; Qin, W.; Ghaziaskar, H.S.; Xu, C. (Charles) Catalytic conversion of glycerol for sustainable production of solketal as a fuel additive: A review. Renew. Sustain. Energy Rev. 2016, 56, 1022-1031. [CrossRef]

2. Barbosa, S.L.; Lima, P.C.; dos Santos, W.T.P.; Klein, S.I.; Clososki, G.C.; Caires, F.J. Oxygenated biofuels: Synthesis of fatty acid solketal esters with a mixture of sulfonated silica and (Bu4N)(BF4) catalyst. Catal. Commun. 2019, 120, 76-79. [CrossRef]

3. Sankaranarayanan, S.; Jindapon, W.; Ngamcharussrivichai, C. Valorization of biodiesel plant-derived products via preparation of solketal fatty esters over calcium-rich natural materials derived oxides. J. Taiwan Inst. Chem. Eng. 2017, 81, 57-64. [CrossRef]

4. Itabaiana, I.; Gonçalves, K.M.; Cordeiro, Y.M.L.; Zoumpanioti, M.; Leal, I.C.R.; Miranda, L.S.M.; de Souza, R.O.M.A.; Xenakis, A. Kinetics and mechanism of lipase catalyzed monoacylglycerols synthesis. J. Mol. Catal. B Enzym. 2013, 96, 34-39. [CrossRef]

5. Johny, J.; Jatla, A.; Eruva, V.K.; Misra, S.; Kaki, S.S. Synthesis, characterization and evaluation of 1-monoacylglycerols of unsaturated fatty acids as potential bioactive lipids. Grasas Aceites 2019, 70, e325. [CrossRef]

6. Machado, A.C.O.; da Silva, A.A.T.; Borges, C.P.; Simas, A.B.C.; Freire, D.M.G. Kinetic resolution of $(R, S)$-1,2-isopropylidene glycerol (solketal) ester derivatives by lipases. J. Mol. Catal. B: Enzym. 2011, 69, 42-46. [CrossRef]

7. Boncel, S.; Zniszczoł, A.; Szymańska, K.; Mrowiec-Białoń, J.; Jarzębski, A.; Walczak, K.Z. Alkaline lipase from Pseudomonas fluorescens non-covalently immobilised on pristine versus oxidised multi-wall carbon nanotubes as efficient and recyclable catalytic systems in the synthesis of solketal esters. Enzyme Microb. Technol. 2013, 53, 263-270. [CrossRef]

8. Zniszczoł, A.; Herman, A.P.; Szymańska, K.; Mrowiec-Białoń, J.; Walczak, K.Z.; Jarzębski, A.; Boncel, S. Covalently immobilized lipase on aminoalkyl-, carboxy- and hydroxy-multi-wall carbon nanotubes in the enantioselective synthesis of Solketal esters. Enzyme Microb. Technol. 2016, 87-88, 61-69. [CrossRef]

9. Neamtu, C.; Stepan, E.; Plesu, V.; Bozga, G.; Tuluc, A. Synthesis and characterization of new solketal alkylesters usable as diesel biobased fuel additives. Rev. Chimie 2019, 70, 1167-1172. [CrossRef]

10. Romano, D.; Ferrario, V.; Molinari, F.; Gardossi, L.; Montero, J.M.S.; Torre, P.; Converti, A. Kinetic resolution

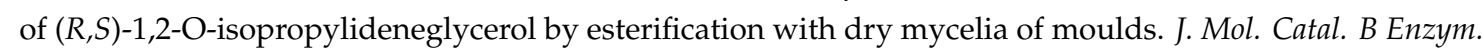
2006, 41, 71-74. [CrossRef]

11. Torregrosa, R.; Yara-Varón, E.; Balcells, M.; Torres, M.; Canela-Garayoa, R. Entirely solvent-free biocatalytic synthesis of solketal fatty esters from soybean seeds. C. R. Chimie 2016, 19, 749-753. [CrossRef]

12. Torregrosa, R.; Balcells, M.; Torres, M.; Canela-Garayoa, R. Chemoenzymatic solvent-free synthesis of 1-monopalmitin using a microwave reactor. Nat. Prod. Commun. 2014, 9, 1095-1098. [CrossRef]

13. Ortiz, C.; Ferreira, M.L.; Barbosa, O.; dos Santos, J.C.; Rodrigues, R.C.; Berenguer-Murcia, Á.; Briand, L.E.; Fernandez-Lafuente, R. Novozym 435: the "perfect" lipase immobilized biocatalyst? Catal. Sci. Technol. 2019, 9, 2380-2420. [CrossRef]

14. Garcia-Galan, C.; Berenguer-Murcia, Á.; Fernandez-Lafuente, R.; Rodrigues, R.C. Potential of different enzyme immobilization strategies to improve enzyme performance. Adv. Synth. Catal. 2011, 353, $2885-2904$. [CrossRef]

15. Barbosa, O.; Ortiz, C.; Berenguer-Murcia, Á.; Torres, R.; Rodrigues, R.C.; Fernandez-Lafuente, R. Strategies for the one-step immobilization-purification of enzymes as industrial biocatalysts. Biotechnol. Adv. 2015, 33, 435-456. [CrossRef]

16. Manoel, E.A.; dos Santos, J.C.S.; Freire, D.M.G.; Rueda, N.; Fernandez-Lafuente, R. Immobilization of lipases on hydrophobic supports involves the open form of the enzyme. Enzyme Microb. Technol. 2015, 71, 53-57. [CrossRef]

17. Virgen-Ortíz, J.J.; Tacias-Pascacio, V.G.; Hirata, D.B.; Torrestiana-Sanchez, B.; Rosales-Quintero, A.; Fernandez-Lafuente, R. Relevance of substrates and products on the desorption of lipases physically adsorbed on hydrophobic supports. Enzyme Microb. Technol. 2017, 96, 30-35. [CrossRef] 
18. Rodrigues, R.C.; Virgen-Ortíz, J.J.; dos Santos, J.C.S.; Berenguer-Murcia, Á.; Alcantara, A.R.; Barbosa, O.; Ortiz, C.; Fernandez-Lafuente, R. Immobilization of lipases on hydrophobic supports: immobilization mechanism, advantages, problems, and solutions. Biotechnol. Adv. 2019, 37, 746-770. [CrossRef]

19. Derewenda, U.; Swenson, L.; Green, R.; Wei, Y.; Yamaguchi, S.; Joerger, R.; Haas, M.J.; Derewenda, Z.S. Current progress, in crystallographic studies of new lipases from filamentous fungi. Protein Eng. Des. Sel. 1994, 7, 551-557. [CrossRef]

20. Verger, R. 'Interfacial activation' of lipases: Facts and artifacts. Trends Biotechnol. 1997, 15, 32-38. [CrossRef]

21. Alves, M.D.; Aracri, F.M.; Cren, É.C.; Mendes, A.A. Isotherm, kinetic, mechanism and thermodynamic studies of adsorption of a microbial lipase on a mesoporous and hydrophobic resin. Chem. Eng. J. 2017, 311, 1-12. [CrossRef]

22. Alves, M.D.; Cren, É.C.; Mendes, A.A. Kinetic, thermodynamic, optimization and reusability studies for the enzymatic synthesis of a saturated wax ester. J. Mol. Catal. B Enzym. 2016, 133, S377-S387. [CrossRef]

23. Machado, N.B.; Miguez, J.P.; Bolina, I.C.A.; Salviano, A.B.; Gomes, R.A.B.; Tavano, O.L.; Luiz, J.H.H.; Tardioli, P.W.; Cren, É.C.; Mendes, A.A. Preparation, functionalization and characterization of rice husk silica for lipase immobilization via adsorption. Enzyme Microb. Technol. 2019, 128, 9-21. [CrossRef] [PubMed]

24. Zeng, M.; Che, Z.; Liang, Y.; Wang, B.; Chen, X.; Li, H.; Deng, J.; Zhou, Z. GC-MS based plasma metabolic profiling of type 2 diabetes mellitus. Chromatographia 2009, 69, 941-948. [CrossRef]

25. Bunka, F.; Pavlínek, V.; Hrabě, J.; Rop, O.; Janiš, R.; Krejčí, J. Effect of 1-Monoglycerides on Viscoelastic Properties of Processed Cheese. Int. J. Food Prop. 2007, 10, 819-828. [CrossRef]

26. Kirchmeier, M.J.; Anderson, D.E. Methods and Compositions for Therapeutic Agents; WO 2013/111012 A2; Variation Biotechnologies Inc.: Gatineau, CA, USA, 2013.

27. Fernandez-Lafuente, R. Lipase from Thermomyces lanuginosus: Uses and prospects as an industrial biocatalyst. J. Mol. Catal. B Enzym. 2010, 62, 197-212. [CrossRef]

28. Rios, N.S.; Pinheiro, B.B.; Pinheiro, M.P.; Bezerra, R.M.; dos Santos, J.C.S.; Barros Gonçalves, L.R. Biotechnological potential of lipases from Pseudomonas: Sources, properties and applications. Process Biochem. 2018, 75, 99-120. [CrossRef]

29. Benjamin, S.; Pandey, A. Candida rugosa lipases: Molecular biology and versatility in biotechnology. Yeast 1998, 14, 1069-1087. [CrossRef]

30. De Maria, P.D.; Alcantara, A.R.; Carballeira, J.D.; de la Casa, R.M.; Garcia-Burgos, C.A.; Hernaiz, M.J.; Sánchez-Montero, J.M.; Sinisterra, J.V. Candida rugosa lipase: A traditional and complex biocatalyst. Curr. Org. Chem. 2006, 10, 1053-1066. [CrossRef]

31. De Maria, P.D.; Sánchez-Montero, J.M.; Sinisterra, J.V.; Alcántara, A.R. Understanding Candida rugosa lipases: An overview. Biotechnol. Adv. 2006, 24, 180-196. [CrossRef]

32. Tischer, W.; Kasche, V. Immobilized enzymes: Crystals or carriers? Trends Biotechnol. 1999, 17, $326-335$. [CrossRef]

33. Marty, A.; Dossat, V.; Condoret, J.-S. Continuous operation of lipase-catalyzed reactions in nonaqueous solvents: Influence of the production of hydrophilic compounds. Biotechnol. Bioeng. 1997, 56, 232-237. [CrossRef]

34. Colombié, S.; Tweddell, R.J.; Condoret, J.-S.; Marty, A. Water activity control: A way to improve the efficiency of continuous lipase esterification. Biotechnol. Bioeng. 1998, 60, 362-368. [CrossRef]

35. Martins, A.B.; Schein, M.F.; Friedrich, J.L.R.; Fernandez-Lafuente, R.; Ayub, M.A.Z.; Rodrigues, R.C. Ultrasound-assisted butyl acetate synthesis catalyzed by Novozym 435: Enhanced activity and operational stability. Ultrason. Sonochem. 2013, 20, 1155-1160. [CrossRef] [PubMed]

36. Fallavena, L.P.; Antunes, F.H.F.; Alves, J.S.; Paludo, N.; Ayub, M.A.Z.; Fernandez-Lafuente, R.; Rodrigues, R.C. Ultrasound technology and molecular sieves improve the thermodynamically controlled esterification of butyric acid mediated by immobilized lipase from Rhizomucor miehei. RSC Adv. 2014, 4, 8675-8681. [CrossRef]

37. Paludo, N.; Alves, J.S.; Altmann, C.; Ayub, M.A.Z.; Fernandez-Lafuente, R.; Rodrigues, R.C. The combined use of ultrasound and molecular sieves improves the synthesis of ethyl butyrate catalyzed by immobilized Thermomyces lanuginosus lipase. Ultrason. Sonochem. 2015, 22, 89-94. [CrossRef]

38. Séverac, E.; Galy, O.; Turon, F.; Pantel, C.A.; Condoret, J.-S.; Monsan, P.; Marty, A. Selection of CalB immobilization method to be used in continuous oil transesterification: Analysis of the economical impact. Enzyme Microb. Technol. 2011, 48, 61-70. [CrossRef] 
39. Graebin, N.G.; Martins, A.B.; Lorenzoni, A.S.G.; Garcia-Galan, C.; Fernandez-Lafuente, R.; Ayub, M.A.Z.; Rodrigues, R.C. Immobilization of lipase B from Candida antarctica on porous styrene-divinylbenzene beads improves butyl acetate synthesis. Biotechnol. Progr. 2012, 28, 406-412. [CrossRef]

40. Friedrich, J.L.R.; Peña, F.P.; Garcia-Galan, C.; Fernandez-Lafuente, R.; Ayub, M.A.Z.; Rodrigues, R.C. Effect of immobilization protocol on optimal conditions of ethyl butyrate synthesis catalyzed by lipase B from Candida antarctica. J. Chem. Technol. Biotechnol. 2013, 88, 1089-1095. [CrossRef]

41. Lage, F.A.P.; Bassi, J.J.; Corradini, M.C.C.; Todero, L.M.; Luiz, J.H.H.; Mendes, A.A. Preparation of a biocatalyst via physical adsorption of lipase from Thermomyces lanuginosus on hydrophobic support to catalyze biolubricant synthesis by esterification reaction in a solvent-free system. Enzyme Microb. Technol. 2016, 84, 56-67. [CrossRef]

42. Song, Q.-X.; Wei, D.-Z. Study of Vitamin C ester synthesis by immobilized lipase from Candida sp. J. Mol. Catal. B Enzym. 2002, 18, 261-266. [CrossRef]

43. Páez, B.C.; Medina, A.R.; Rubio, F.C.; Moreno, P.G.; Grima, E.M. Modeling the effect of free water on enzyme activity in immobilized lipase-catalyzed reactions in organic solvents. Enzyme Microb. Technol. 2003, 33, 845-853. [CrossRef]

44. Cui, C.; Zhen, Y.; Qu, J.; Chen, B.; Tan, T. Synthesis of biosafe isosorbide dicaprylate ester plasticizer by lipase in a solvent-free system and its sub-chronic toxicity in mice. RSC Adv. 2016, 6, 11959-11966. [CrossRef]

45. Liaquat, M. Optimized synthesis of (Z)-3-hexen-1-yl caproate using germinated rapeseed lipase in organic solvent. J. Mol. Catal. B Enzym. 2011, 68, 59-65. [CrossRef]

46. Ye, R.; Hayes, D.G. Optimization of the solvent-free lipase-catalyzed synthesis of fructose-oleic acid ester through programming of water removal. J. Am. Oil Chem. Soc. 2011, 88, 1351-1359. [CrossRef]

47. Boudrant, J.; Woodley, J.M.; Fernandez-Lafuente, R. Parameters necessary to define an immobilized enzyme preparation. Process Biochem. 2019, in press. [CrossRef]

48. Barbosa, M.S.; Freire, C.C.C.; Almeida, L.C.; Freitas, L.S.; Souza, R.L.; Pereira, E.B.; Mendes, A.A.; Pereira, M.M.; Lima, Á.S.; Soares, C.M.F. Optimization of the enzymatic hydrolysis of Moringa oleifera Lam oil using molecular docking analysis for fatty acid specificity. Biotechnol. Appl. Biochem. 2019, 66, 823-832. [CrossRef]

49. Bassi, J.J.; Todero, L.M.; Lage, F.A.P.; Khedy, G.I.; Ducas, J.D.; Custódio, A.P.; Pinto, M.A.; Mendes, A.A. Interfacial activation of lipases on hydrophobic support and application in the synthesis of a lubricant ester. Int. J. Biol. Macromol. 2016, 92, 900-909. [CrossRef]

50. Lima, L.C.D.; Peres, D.G.C.; Mendes, A.A. Kinetic and thermodynamic studies on the enzymatic synthesis of wax ester catalyzed by lipase immobilized on glutaraldehyde-activated rice husk particles. Bioprocess Biosyst. Eng. 2018, 41, 991-1002. [CrossRef]

51. Badgujar, K.C.; Bhanage, B.M. Immobilization of lipase on biocompatible co-polymer of polyvinyl alcohol and chitosan for synthesis of laurate compounds in supercritical carbon dioxide using response surface methodology. Process Biochem. 2015, 50, 1224-1236. [CrossRef]

52. Badgujar, K.C.; Bhanage, B.M. The combine use of ultrasound and lipase immobilized on co-polymer matrix for efficient biocatalytic application studies. J. Mol. Catal. B: Enzym. 2015, 122, 255-264. [CrossRef]

53. Dörmő, N.; Bélafi-Bakó, K.; Bartha, L.; Ehrenstein, U.; Gubicza, L. Manufacture of an environmental-safe biolubricant from fusel oil by enzymatic esterification in solvent-free system. Biochem. Eng. J. 2004, 21, 229-234. [CrossRef]

54. Miguez, J.P.; Gama, R.S.; Bolina, I.C.A.; de Melo, C.C.; Cordeiro, M.R.; Hirata, D.B.; Mendes, A.A. Enzymatic synthesis optimization of a cosmetic ester catalyzed by a homemade biocatalyst prepared via physical adsorption of lipase on amino-functionalized rice husk silica. Chem. Eng. Res. Des. 2018, 139, 296-308. [CrossRef]

55. Bolina, I.C.A.; Salviano, A.B.; Tardioli, P.W.; Cren, É.C.; Mendes, A.A. Preparation of ion-exchange supports via activation of epoxy- $\mathrm{SiO}_{2}$ with glycine to immobilize microbial lipase-Use of biocatalysts in hydrolysis and esterification reactions. Int. J. Biol. Macromol. 2018, 120, 2354-2365. [CrossRef]

56. Gama, R.S.; Bolina, I.C.A.; Cren, É.C.; Mendes, A.A. A novel functionalized $\mathrm{SiO}_{2}$-based support prepared from biomass waste for lipase adsorption. Mater. Chem. Phys. 2019, 234, 146-150. [CrossRef]

57. Holetz, F.B.; Pessini, G.L.; Sanches, N.R.; Cortez, D.A.G.; Nakamura, C.V.; Dias Filho, B.P. Screening of some plants used in the Brazilian folk medicine for the treatment of infectious diseases. Mem. Inst. Oswaldo Cruz 2002, 97, 1027-1031. [CrossRef] 
58. Du, L.; Jiang, Z.; Xu, L.; Zhou, N.; Shen, J.; Dong, Z.; Shen, L.; Wang, H.; Luo, X. Microfluidic reactor for lipase-catalyzed regioselective synthesis of neohesperidin ester derivatives and their antimicrobial activity research. Carbohydr. Res. 2018, 455, 32-38. [CrossRef]

59. Bradford, M.M. A rapid and sensitive method for the quantitation of microgram quantities of protein utilizing the principle of protein-dye binding. Anal. Biochem. 1976, 72, 248-254. [CrossRef]

60. Alexander, B.D. Reference Method for broth Dilution Antifungal Susceptibility Testing of Yeasts, 4th ed.; Clinical and Laboratory Standards Institute: Wayne, NJ, USA, 2017.

61. Patel, J.B. Methods for Dilution Antimicrobial Susceptibility Tests for Bacteria that Grow Aerobically, 10th ed.; Clinical and Laboratory Standards Institute: Wayne, NJ, USA.

62. Sarker, S.D.; Nahar, L.; Kumarasamy, Y. Microtitre plate-based antibacterial assay incorporating resazurin as an indicator of cell growth, and its application in the in vitro antibacterial screening of phytochemicals. Methods 2007, 42, 321-324. [CrossRef]

(C) 2020 by the authors. Licensee MDPI, Basel, Switzerland. This article is an open access article distributed under the terms and conditions of the Creative Commons Attribution (CC BY) license (http://creativecommons.org/licenses/by/4.0/). 